\title{
PENGEMBANGAN PULAU TARAKAN SEBAGAI PANGKALAN MILITER UDARA UTAMA DI WILAYAH KALIMANTAN UTARA (STUDI KASUS: LANUD ANANG BUSRA - TARAKAN, KALIMANTAN UTARA)
}

\author{
Andrea Abdul Rahman Azzqy ${ }^{1)}$ dan Anggun Puspitasari ${ }^{2)}$ \\ ${ }^{1,2}$ Ilmu Hubungan Internasional, Fakultas Ilmu Sosial dan Ilmu Politik, Universitas Budi Luhur \\ ${ }^{1,2}$ Jl. Ciledug Raya, Petukangan Utara, Kec. Pesanggrahan, Kota Jakarta Selatan, \\ Daerah Khusus Ibukota Jakarta, 12260 \\ E-mail : andrea.abdulrachman@budiluhur.ac.id ${ }^{1)}$, anggun.puspitasari@budiluhur.ac.id ${ }^{2)}$
}

\begin{abstract}
ABSTRAK
Pada teori keamanan nasional, terdapat beberapa alasan mengapa penyelidikan ilmiah dalam keamanan intelijen merupakan suatu analisis penting terutama untuk mengurangi ketidak-akurat data dalam suatu perumusan kebijakan. Pada lingkungan strategis yang kompleks, aktivitas atau peristiwa kecil sekalipun dalam pembentukan kebijakan keamanan dapat mengakibatkan efek yang luar biasa dan bersifat konfliktual karena memiliki variabel-variabel sensitif. Dengan demikian dapat dilihat bahwa terdapat urgensi untuk meminimalisir ketidakpastian strategis dalam produk analisis mengenai suatu kebijakan keamanan, salah satunya adalah mengenai pengamanan daerah perbatasan. Dalam konteks Indonesia, terdapat beberapa variabel yang harus dikaji terkait dengan perencanaan pembangunan infrastruktur pertahanan di daerah perbatasan terluar. Salah satu variabel utama adalah aspek sosial budaya untuk mengukur keterbukaan masyarakat terhadap pembangunan infrastruktur keamanan. Kesediaan dan keterbukaan masyarakat merupakan salah satu indikator utama kesuksesan sebuah penerapan kebijakan. Selaras dengan hal tersebut, pada penelitian ini akan difokuskan kajian mengenai Pengembangan Pulau Tarakan Sebagai Pangkalan Militer Udara Utama di Wilayah Kalimantan Utara dengan Studi Kasus: Lanud Anang Busra - Tarakan, Kalimantan Utara. Analisis terhadap peran dan keberadaan Kapal perang dan Pesawat TNI di wilayah perbatasan terluar Indonesia sebagai salah satu infrastruktur pertahanan harus dikorelasikan dengan kondisi keterbukaan masyarakat wilayah perbatasan di tempat tersebut, serta berbagai kepentingan nasional yang harus diamankan. Data dalam penelitian ini akan diolah dengan menggunakan pendekatan kualitatif untuk memahami perspektif masyarakat dengan mendalam.
\end{abstract}

Kata Kunci: Tarakan, Pangkalan Militer, Keamanan Nasional, Perbatasan, Kalimantan

\section{PENDAHULUAN}

Masalah pengelolaan dan pertahanan di wilayah perbatasan sangat terkait erat dengan konsepsi dasar tentang negara sebagai entitas yang memiliki kedaulatan, penduduk, dan wilayah serta tafsir atau persepsi atas ancaman yang dihadapi. Dengan demikian, pengelolaan dan pertahanan wilayah perbatasan dapat disimpulkan sebagai segala upaya untuk mewujudkan eksistensi suatu negara, yang ditandai dengan terlindungnya kedaulatan, penduduk dan wilayah dari pelbagai jenis ancaman. Pengelolaan dan pertahanan wilayah perbatasan NKRI juga harus dipahami sebagai fungsi-fungsi yang bersifat permanen, selama eksistensi negara ada. Hal yang selalu akan berubah dan mengalami penyesuaian adalah, "analisis ancaman (threat assessment) yang mempengaruhi besaran sumber daya dan kekuatan yang diperlukan dan bagaimana sumber daya dan kekuatan itu diorganisir untuk keperluan pengelolaan dan pertahanan wilayah perbatasan." Analisis ancaman yang menentukan apakah ancaman tersebut bersifat internal atau eksternal, serta apakah penanganannya bersifat bertahan (defensif) atau menyerang (offensive).
Termasuk apakah penanganan pengelolaan dan pertahanan wilayah perbatasan akan lebih di titik beratkan pada kawasan tertentu dengan memperhatikan derajat ancaman atau potensi ancaman berdasarkan kondisi geografis sebuah negara (Kant, 2015).

Berhubungan dengan masalah pengembangan wilayah perbatasan khususnya di bagian utara Kalimantan, yakni Provinsi Kalimantan Utara, menjadi semakin krusial dan perlu mendapatkan perhatian serius dari pemerintah baik di tingkat Pusat maupun Daerah. Selama ini harus dipahami bahwa pembangunan sosioekonomi di wilayah perbatasan cenderung terabaikan, sehingga disadari secara realistis, jika kabupaten perbatasan semisal Kabupaten Malinau maupun Kabupaten Kutai Barat tergolong sebagai kabupaten tertinggal di Indonesia. Kondisi ketertinggalan wilayah tadi sering memunculkan sindiran bahwa wilayah perbatasan merupakan halaman belakang "backyards" dari negara Indonesia. Seiring dengan mencuatnya konflik antara Indonesia dan Malaysia tentang blok laut Ambalat dan potensi konflik serta keamanan dengan Filipina, terutama dalam masalah maritim dan terorisme, muncul pula kesadaran dan komitmen yang lebih baik 
dari jajaran pemerintah (baik Pusat maupun Daerah) untuk mengubah wajah perbatasan sebagai "halaman depan". Perubahan paradigma ini jelas menuntut perubahan kebijakan, baik menyangkut prioritas penetapan program pembangunan, alokasi anggaran pembangunan daerah, terutama menyangkut aspek pertahanan dan keamanan di wilayah tersebut (Wangke, 2017).

Fokus bahasan adalah Kota Tarakan, yang terdiri dari 4 kecamatan dan 18 kelurahan. Keempat kecamatan tersebut adalah Tarakan Timur, Tarakan Tengah, Tarakan Barat dan Tarakan Utara. Luas wilayah Kota Tarakan adalah $\pm 657,33 \mathrm{~km} 2$ yang terdiri dari daratan seluas $\pm 250,8 \mathrm{~km} 2$ dan lautan seluas $\pm 406,53 \mathrm{~km} 2$. Kota Tarakan terletak di Provinsi Kalimantan Utara (Kaltara) yang merupakan kota pulau, Tarakan menjadi salah satu kota terbesar kedua setelah ibukota provinsi Kaltara yaitu Tanjung Selor. Posisi strategis yang dimiliki oleh Tarakan adalah sebagai pintu gerbang dan halaman depan Indonesia yang menghadap ke Malaysia dan Ambang Batas Laut (Ambalat) antara Indonesia, Malaysia serta Filipina (Thontowi, 2015).

Implementasi kebijakan pembangunan kekuatan yang berupa pangkalan militer di pulau Tarakan tersebut telah terwujud melalui Peraturan Daerah Kota Tarakan tahun 2012, mengenai "Rencana Tata Ruang Wilayah Kota Tarakan Tahun 2012 - 2032" (Tarakan, 2012). Indikasi terukur dari penggalian fakta menunjukkan bahwa, pemerintah pusat dan daerah berupaya secara konseptual dan rencana pelaksanaan teknisnya dapat menghadirkan sinergis antara rencana tata ruang daerah dengan tata ruang pertahanan, sehingga penguatan pertahanan nasional dapat terakomodir, utamanya adalah pada sisi pencapaian tujuan, berupa menciptakan penguatan pertahanan dan keamanan dalam bentuk pangkalan militer, menaikkan status pangkalan militer existing, berujung pada jawaban dari keinginan pemerintah sendiri dalam konteks daya tangkal atau deterrence .

Berdasarkan dokumen "Perkembangan Lingkungan Strategis dan Prediksi Ancaman Tahun 2008" yang dikeluarkan oleh Departemen Pertahanan Republik Indonesia pada Januari 2008, dalam bab Lingkungan Strategis Regional, saat ini yang perlu diperhatikan Indonesia adalah situasi di kawasan Asia Tenggara, yaitu isu stabilitas keamanan regional yang mewarnai kawasan ini, seperti konflik yang bersumber pada klaim teritorial, keamanan jalur pelayaran dan perdagangan, terorisme, perompakan, bajak laut dan penyelundupan. Potensi ancaman yang juga dijabarkan dalam dokumen tersebut, salah satunya adalah keamanan perbatasan. Permasalahan perbatasan dengan negara tetangga masih banyak yang tersisa, dan di antaranya rawan menjadi potensi konflik terbatas dengan Indonesia. Permasalahan perbatasan di Malaysia, perairan Ambalat, dan penerbangan ilegal yang melewati wilayah udara Indonesia (Al Syahrin, 2018).
Penulisan kajian ini membahas wilayah udara di dalam wilayah tiga negara, yaitu Indonesia, Malaysia, dan Filipina. Tiga negara dianggap mewakili wilayahwilayah yang dicakup dalam bahasan ini, adapun peristiwa terakhir yang terjadi terkait pelanggaran udara nasional, yaitu mengenai masuknya sebuah pesawat asing yang masuk kedalam wilayah udara Republik Indonesia tanpa izin, pesawat tersebut diawaki oleh pilot yang berkewarganegaraan Amerika Serikat dan menjalankan sebuah penerbangan khusus dari arah Filipina. Selain kejadian tersebut, juga terdapat kontestasi atau perebutan kendali mengenai wilayah Ambalat di area selat sulawesi yang diperebutkan antara Indonesia dan Malaysia. Hal ini juga selaras dengan pernyataan Menko Polhukam Wiranto mengenai pengamanan perbatasan di wilayah Indonesia, dalam Rapat Koordinasi Pengendalian Pengelolaan Perbatasan Negara 2019. Wiranto menyebutkan ada sekitar 1.400 rute yang tak resmi di perbatasan Indonesia dengan Malaysia di wilayah Kalimantan Utara. Adanya jalur ilegal tersebut menyebabkan berbagai permasalahan, dari penyelundupan narkoba hingga illegal logging (Lubis, 2018).

Kondisi dunia internasional pasca dekade 1990-an atau secara konseptual dalam kajian hubungan internasional dikenal dengan era pasca perang dingin, telah menciptakan transformasi baru secara dinamis pada struktur tatanan global. Tatanan yang bersifat unipolaritas pada dekade 1990-an telah berganti menuju struktur multi-polaritas atau bahkan banyak pengamat yang menyebutnya sebagai era non-polaritas seiring dengan mulai tumbuh dan terlibatnya berbagai aktor hubungan internasional dengan berbagai tingkat kekuatannya.

Namun, di tengah kompleksitas keterlibatan berbagai aktor global tersebut, sketsa struktur tatanan global tetap menjadi suatu wilayah yang dapat digambarkan secara gamblang, termasuk di dalam dimensi aktor global yang terlibat. Indonesia menjadi salah satu kekuatan aktor Regional-Global yang pada waktu tersebut geliat dan pengaruhnya dapat diperhitungkan tidak saja dalam skala regional, namun juga secara global. Begitu juga eksistensi ini masih terjaga hingga saat ini, di tengah kompleksitas hubungan internasional abad 21. (Amaritasari, 2015) dalam buku Security: A New Framework for Analysis melihat konsep keamanan dari cara pandang yang berbeda, 'narrow' vs 'wide' conceptions. Buzan membedakan cara pandang tradisional yang mengidentifikasikan keamanan secara militer pada level negara menjadi fokus dalam isu-isu keamanan. Sedangkan dalam cara pandang nontradisional, batasan isu keamanan dalam level yang bervariasi menjadi fokus dalam isu isu keamanan modern. Konsep yang luas ini melihat isu-isu lingkungan, manajemen sumber daya alam, penyebaran penyakit, kejahatan transnational dan krisis ekonomi sebagai isu-isu keamanan. 
Dalam pendekatan tradisional, keamanan secara sederhana diartikan sebagai keamanan sebuah negara yang dapat diancam oleh kekuatan militer negara lain dan harus dipertahankan melalui kekuatan militer negara itu sendiri. Dalam pendekatan ini, negara (state) menjadi subjek dan objek dari upaya mengejar kepentingan keamanan. Pandangan kelompok ini menilai bahwa semua fenomena politik dan hubungan internasional adalah fenomena tentang negara.

Dalam alam pemikiran tradisional ini negara menjadi inti dalam upaya menjaga keamanan negara. Menurut kelompok ini pula, keamanan didefinisikan secara terbatas pada hubungan antara negara-bangsa meliputi berbagai persoalan seperti keseimbangan kekuatan (balance of power) dan strategi militer. Di masa lalu, sebagian besar peneliti dan pejabat pemerintah sering menempatkan ancaman terhadap keamanan nasional sebagai prioritas utama di antara semua masalah keamanan, misalnya, konflik militer, terorisme, separatisme, ekstremisne agama, penyelundupan narkoba atau keamanan laut.

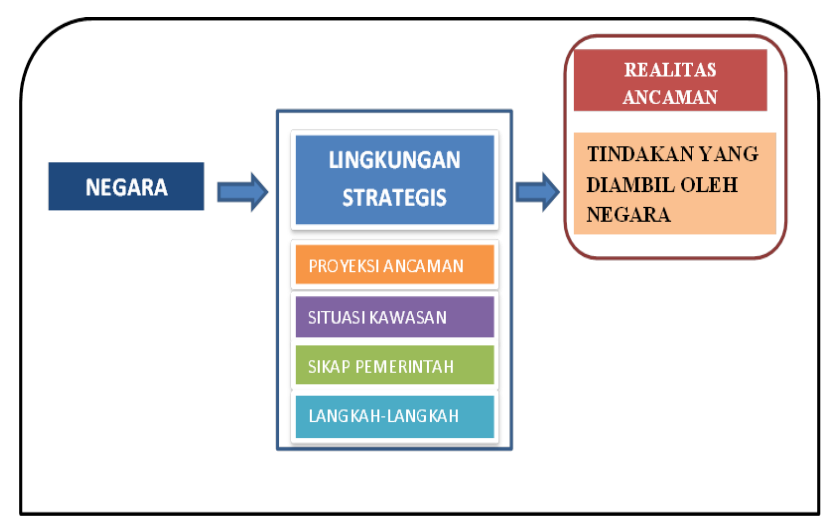

\section{Gambar 1. Alur Pikir Mengenai Lingkungan Strategis}

Dalam Buku Putih Pertahanan, ancaman tradisional ini digolongkan ke dalam ancaman militer, yaitu ancaman yang menggunakan kekuatan bersenjata dan terorganisasi dan dinilai mempunyai kemampuan membahayakan kedaulatan negara, keutuhan wilayah negara, dan keselamatan segenap bangsa. Ancaman militer dapat pula terjadi dalam bentuk pemberontakan bersenjata. Pemberontakan tersebut pada dasarnya merupakan ancaman yang timbul dan dilakukan oleh pihak-pihak tertentu di dalam negeri, tetapi pemberontakan bersenjata tidak jarang disokong oleh kekuatan asing, baik secara terbuka maupun secara tertutup atau tersamar.

Selanjutnya, seiring dengan berakhirnya perang dingin, diskursus mengenai keamanan pun bergeser tidak lagi hanya terfokus pada aktor negara. Berbeda dengan pendekatan tradisional, konsepsi keamanan dengan pendekatan non-tradisional ditekankan kepada kepentingan keamanan pelaku-pelaku bukan negara (non-state actors). Perkembangan isu-isu strategis seperti globalisasi, demokratisasi, penegakan HAM dan fenomena terorisme telah memperluas cara pandang dalam melihat kompleksitas ancaman yang ada dan mempengaruhi perkembangan konsepsi keamanan. Ancaman tidak lagi hanya berupa ancaman militer tetapi juga meliputi ancaman ideologi, ancaman politik, ancaman sosial budaya dan ancaman ekonomi.

Konsepsi ini berkembang seiring dengan menurunnya intensitas ancaman militer yang menjadikan kedaulatan negara sebagai target, akan tetapi di sisi lain menunjukkan adanya peningkatan ancaman terhadap keamanan manusia pada aspek lain seperti kemiskinan, penyakit menular, bencana alam, kerusakan lingkungan hidup dan lainnya. Pada akhirnya Indonesia sebagai negara berdaulat merasa perlu untuk merespons isu-isu keamanan yang berasal dari dalam negeri maupun luar negeri. Terlebih lagi banyak faktor yang menghadapkan negara dalam posisi siaga dalam situasi ketidakpastian dari luar negeri yang berupa ancaman tradisional maupun ancaman non-tradisional. Maka wilayah yang berbatasan langsung dengan hal-hal tersebut diatas seperti pulau Tarakan, dirasa perlu untuk membuat instalasi aju (Hutri, Sitorus and Santosa, 2020)sebagai langkah defensif aktif negara dalam mengatasi ancaman yang hadir.

Salah satu ancaman non tradisional (nirmiliter) dapat berasal dari aspek sosial budaya yang memicu konflik antar sipil-dan militer di wilayah pembangunan pangkalan militer. Pada tataran ini, posisi Pemerintah Daerah menjadi begitu penting, sesuai dengan yang tertera pada Buku Putih Pertahanan Indonesia 2015 bahwa dalam skema sistem pertahanan negara, pertahanan nirmiliter menempatkan Kementerian/Lembaga lain dan Pemerintah Daerah sebagai unsur utama yang harus berperan dalam mengantisipasi dan mencegah terjadinya ancaman nonmiliter melalui penataan ruang wilayah nasional dan terutama daerah dengan tata ruang wilayah pertahanan untuk mewujudkan ruang pertahanan yang tangguh. Pembangunan wilayah pertahanan negara harus diselenggarakan secara terintegrasi antara unsur Pemerintah dan Pemerintah Daerah agar dapat secara maksimal menghadapi ancaman nonmiliter baik ancaman nyata maupun ancaman belum nyata (potensial).

Sinergitas penanganan ancaman nirmiliter dan pembangunan tata ruang pertahanan daerah setidaknya melibatkan dua belas sektor yang terdiri dari pemerintah, militer, kepolisian, dan masyarakat sipil. Masing-masing sektor memiliki perwakilan dan/atau pelaksana tugas pokok di daerahnya, termasuk di daerah. Masing-masing penanggung jawab ini memiliki wewenang dan kewajiban tugas. Sinergitas peran ini sangat diperlukan untuk mendorong penanganan ancaman nirmliter dan pembangunan tata ruang pertahanan daerah menjadi lebih efektif dan efisien. Sinergitas peranan antara sipil dan militer ini diharapkan dapat mencapai tujuan-tujuan strategis baik secara makro, mikro dan jangka panjang ataupun menengah, dan pendek. 
Sinergitas pembangunan nasional, pembangunan daerah dan pembangunan pertahanan negara perlu disinkronkan dengan didukung regulasi yang jelas, dengan memperhitungkan sumber daya yang tersedia guna tercapainya kesejahteraan masyarakat yang nyata, baik dalam aspek pendapatan, kesempatan kerja, lapangan usaha, akses terhadap pengambilan kebijakan, berdaya saing, maupun peningkatan indeks pembangunan manusia di wilayah pembangunan pangkalan militer. Sinergitas antar pemangku kepentingan dalam sinergitas pembangunan pertahanan negara merupakan hal yang pokok untuk mencapai pertahanan yang tangguh. Kemudian, sosialisasi kebijakan antar Instansi Vertikal Kementerian/Lembaga dan Pemerintah Daerah perlu dioptimalkan dan diintensipkan sehingga akan tercapai suatu persamaan persepsi dalam pengelolaan dan penyelenggaraan pembangunan pertahanan negara.

\section{RUANG LINGKUP}

Kebijakan pembangunan kekuatan yang berupa pangkalan militer di pulau Tarakan diwujudkan melalui Peraturan Daerah Kota Tarakan tahun 2012, mengenai "Rencana Tata Ruang Wilayah Kota Tarakan Tahun 2012 - 2032"(Tarakan, 2012). Di dalamnya dijelaskan bahwa pada Paragraf 9 Kawasan Peruntukan Lainnya Pasal 43 ayat 1 (d) Kawasan Pertahanan Keamanan, akan diadakan pembangunan dan penguatan sebagai berikut;

1. Pengembangan Kawasan Pangkalan Utama Angkatan Laut (Lantamal) di Kelurahan Mamburungan dan Kelurahan Mamburungan Timur Kecamatan Tarakan Timur;

2. Pengembangan Kawasan Satuan Radar (Satradar) AURI di Kelurahan Mamburungan timur, Kecamatan Tarakan Timur;

3. Pengembangan Polisi Air (POLAIR) di Kelurahan Juata Laut, Kecamatan Tarakan Utara;

4. Pengembangan Batalion Infantri (Yonif) 613 di Juata Kerikil, Kecamatan Tarakan Utara;

5. Pengembangan Komando Distrik Militer (Kodim) di Kelurahan Pamusian, Kecamatan Tarakan Tengah;

6. Pengembangan Pangkalan Angkatan Udara di Kelurahan Karang Anyar Pantai, Kecamatan Tarakan Barat; dan

7. Kawasan Mako Lanal di Kelurahan Sebengkok Kecamatan Tarakan Tengah.

Kemudian pemerintah Kota Tarakan merasa perlu untuk menjelaskan secara terperinci mengenai pembangunan aspek lingkungan strategis dengan menitikberatkan kepada pembangunan Kawasan Strategis, seperti yang tertera pada Bab IV, Penetapan Kawasan Strategis Kota Pasal 46 ayat 1 huruf (a) yang berbunyi " Kawasan Strategis Kota dari Sudut Kepentingan Pertahanan dan Keamanan", serta Pasal 47 yang berisi penjelasan sebagai berikut;
Kawasan strategis kota dari aspek pertahanan dan keamanan sebagaimana dimaksud dalam Pasal 46 ayat (1) huruf a, terdiri atas:

1. Kawasan yang diperuntukkan bagi kepentingan pemeliharaan pertahanan dan keamanan negara berdasarkan geostrategis nasional;

2. Kawasan yang diperuntukkan bagi basis militer, daerah latihan militer, daerah pembuangan amunisi dan peralatan pertahanan lainnya, gudang amunisi, daerah uji coba sistem persenjataan, dan/atau kawasan industri sistem pertahanan;

3. Kawasan Pangkalan Utama Angkatan Laut (Lantamal) di Kelurahan Mamburungan dan Kelurahan Mamburungan Timur Kecamatan Tarakan Timur;

4. Kawasan Satuan Radar (Satradar) Angkatan Udara Republik Indonesia (AURI) di Kelurahan Mamburungan Timur Kecamatan Tarakan Timur.

5. Kawasan pengembangan Polisi Air (POLAIR) di Kelurahan Juata Laut Kecamatan Tarakan Utara;

6. Kawasan Batalion Infanteri (Yonif) 613 di Kelurahan Juata Kerikil Kecamatan Tarakan Utara;

7. Kawasan pengembangan Komando Distrik Militer (Kodim) di Kelurahan Kampung Satu / Skip Kecamatan Tarakan Tengah;

8. Kawasan pangkalan Angkatan Udara di Kelurahan Karang Anyar Pantai Kecamatan Tarakan Barat; dan Kawasan Mako Lanal di Kelurahan Sebengkok Kecamatan Tarakan Tengah.

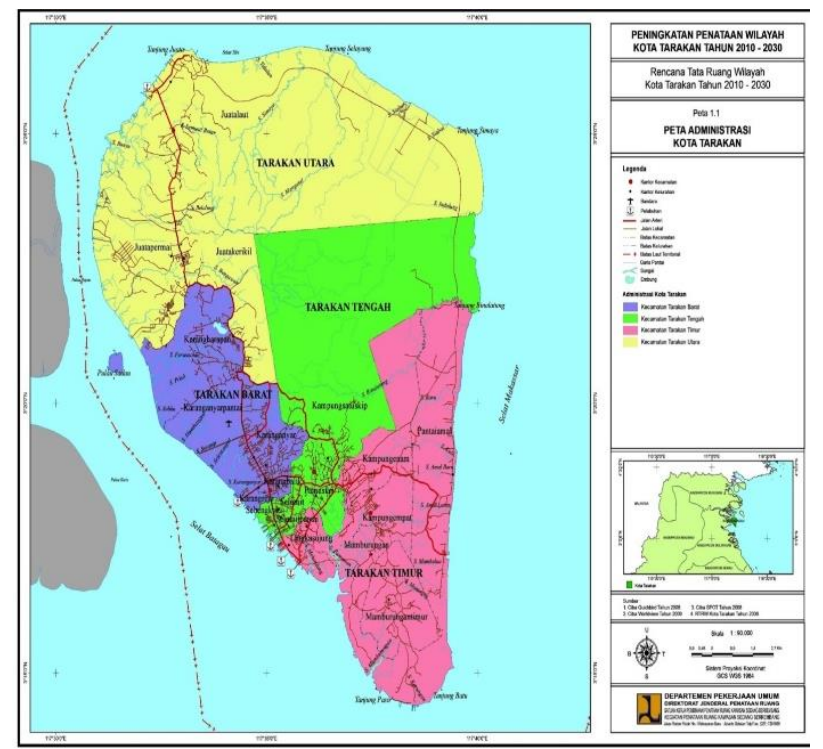

Gambar 2. Peta Rencana Tata Ruang \& Tata Wilayah Kota Tarakan

Kompleksitas (complexity) ancaman yang semakin meningkat, perlombaan senjata antara negara-negara regional Asia Tenggara, situasi yang memanas akibat kasus pembajakan, penyelundupan, serta terorisme (termasuk dalamnya isu-isu perbatasan) menuntut peran aktif rezim politik demokratis yang memerintah dengan memperhatikan pandangan dan pembacaan aktor-aktor 
keamanan serta konsistensi pada kepentingan penjagaan kedaulatan, penduduk dan wilayah. Seiring dengan pergeseran paradigma tersebut terjadi pula pergeseran dan perubahan paradigma keamanan global, keamanan regional serta keamanan nasional, yang sebelumnya merupakan keamanan wilayah (teritorial security) telah bergeser menjadi keamanan manusia (human security). Sehingga pola penanganannya juga berubah dari kerja sama keamanan (security corporative) dan keamanan bersama (collective security) menjadi keamanan komprehensif (security comprehensive). Aktor-aktor yang menangani juga berubah, yang sebelumnya hanya aktor tertentu bergeser ke aktor-aktor yang memiliki otoritas politik dan operasional termasuk civil society. Sebaran konsep dan teknik dalam ranah Pertahanan Negara akhirnya melahirkan apa yang disebut Force Projection (Usmita, 2012).

Tabel 1. Force Projection in National Defense

\begin{tabular}{|l|l|l|}
\hline Konsep & Defence & Offense \\
& Membangun kerja & Pengamatan \\
& sama antara & (intelijen) Kekuatan \\
& negara-negara & Regional dan \\
& kawasan & Senanganan Wilayah \\
& Aktif dalam & Strategis yang \\
& melakukan latihan & berbatasan dengan \\
& militer dengan & Negara-Negara \\
& negara-negara & Tetangga \\
& kawasan & \\
\hline Teknik & Penggunaan & Penguatan Instalasi \\
& kekuatan Industri & dan Pangkalan \\
& militer & Penambahan \\
& Peremajaan & Instalasi teknologi \\
& alutsista berjangka & Peningkatan kualitas \\
& Aktif dalam & personil Pertahanan \\
& melakukan & \& Keamanan \\
& sosialisasi & Peningkatan \\
& kesadaran nasional & Kehadiran di \\
& akan Hankam & Wilayah Lawan \\
& (Bela Negara) & (Perbatasan) \\
& & Peningkatan \\
& & Kemampuan \\
& & Alutsista \\
\hline \multirow{7}{*}{} &
\end{tabular}

Berdasarkan tabel di atas dapat dilihat bahwa aktivitas defence cenderung mengarah kedalam negeri walaupun tetap mengikutsertakan aspek-aspek kerja sama antar negara. Sedangkan aktivitas offense cenderung reaktif dan selalu siaga terhadap situasi yang dinamis, dengan harapan upaya tersebut dapat menekan terjadinya serangan dari lawan (negara-negara luar maupun aktor non-negara).

\section{BAHAN DAN METODE}

Penelitian ini menggunakan analisis kualitatif yang bertujuan untuk menyederhanakan realitas sosial (Miles and Huberman, 2012). Terkait dengan penelitian ini, maka realitas strategis yang disederhanakan adalah hadirnya kebijakan pemerintah terkait dengan rencana pembangunan Pangkalan Aju Militer, yang tidak terlepas dari konteks ketidakpastian maupun situasi dinamis regional maupun global. Jenis Penelitian yang digunakan adalah penelitian eksploratif, deskriptif, analitis dan confirmatory. Penelitian eksploratif berarti menjelaskan ide-ide atau hubungan-hubungan yang baru guna memberikan gambaran mengenai konsep yang digunakan dalam penelitian. Deskriptif menjelaskan, meringkas berbagai kondisi, situasi variabel yang timbul di masyarakat yang menjadi objek penelitian berdasarkan apa yang terjadi. Diharapkan melalui penggunaan jenis penelitian deskriptif, peneliti dapat menyajikan satu gambaran yang terperinci mengenai Pembangunan Pangkalan Aju Militer di Pulau Tarakan dalam kerangka Defence Strategy dan Konsep Pertahanan Keamanan Nasional.

Dalam penelitian ini, peneliti menggunakan dua jenis data yakni data primer dan data sekunder. Menurut Sugiyono (sugiono, 2011), data primer didefinisikan sebagai sumber data yang langsung memberikan data kepada pengumpul data. Pengumpulan data primer yaitu pengumpulan data yang diperoleh secara langsung pada saat melakukan penelitian di lapangan. Data sekunder didefinisikan sebagai sumber yang tidak langsung memberikan data kepada pengumpul data. Data sekunder sejatinya merupakan sumber data primer yang telah diolah lebih lanjut, baik oleh pengambil data primer ataupun oleh pihak lain. Sumber data primer didapatkan dari wawancara dengan stakeholder terkait antara lain, Kepala Dinas Penerangan Angkatan Udara Republik Indonesia, Direktur Jenderal Strategi Pertahanan Kementerian Pertahanan, Komandan Pangkalan Udara Tarakan, Pemerintah Daerah Tarakan, dan perwakilan Masyarakat Tarakan.

Sumber data sekunder dalam penelitian ini lebih banyak berupa statistik ataupun data yang sudah diolah sedemikian rupa. Selain menggunakan data dari artikel berita dan situs resmi pemerintah, peneliti pun menggunakan catatan historis, dokumen, dan arsip seperti Dokumen Kebijakan Pertahanan Negara, Buku Putih Pertahanan yang dipublikasikan oleh Kementerian Pertahanan dan Pemerintah Daerah sebagai data sekunder.

Dalam penelitian ini, dilaksanakan kegiatan tahapan pralapangan, yaitu kegiatan yang dilakukan sebelum peneliti memasuki lapangan. Masing-masing adalah: (1) Penyusunan rancangan awal penelitian, (2) Pengurusan izin penelitian, (3) Penjajakan lapangan dan penyempurnaan rancangan penelitian, (4) Pemilihan dan interaksi dengan subjek dan informan, dan (5) Penyiapan peranti pembantu untuk kegiatan lapangan.

Dilanjutkan dengan tahapan kegiatan lapangan, yaitu kegiatan atau proses pengambilan sampel dalam penelitian, berkaitan dengan bagaimana memilih informan atau situasi sosial tertentu yang dapat memberikan informasi konsisten dan terpercaya mengenai unsur-unsur pusat perhatian penelitian. Proses 
ini berkaitan erat dengan data utama penelitian yang diperoleh berdasarkan interaksi bersama responden menggunakan cara pengamatan maupun wawancara demi mendapatkan informasi.

Analisis data dilakukan pada saat pengumpulan dan setelah selesai pengumpulan data. Tahap ini merupakan tahap pasca lapangan. Adapun analisis data bertujuan untuk mengategorikan data menjadi sederhana sesuai fokus penelitian sehingga lebih mudah untuk dipahami. Menurut Miles dan Huberman, teknik analisis data dilakukan dengan langkah-langkah sebagai berikut:

1. Pengumpulan data

Dalam penelitian ini, penulis menggunakan teknik pengumpulan data dengan studi dokumen resmi serta buku dan jurnal terkait.

2. Reduksi Data

Data yang diperoleh kemudian ditulis dalam bentuk laporan deskriptif dan terperinci. Laporan yang disusun berdasarkan data yang diperoleh kemudian direduksi dan difokuskan pada hal-hal yang penting. Dengan demikian dapat diperoleh gambaran yang lebih tajam tentang hasil penelitian serta mempermudah peneliti untuk mencari data tambahan jika diperlukan. Adapun acuan dalam melakukan reduksi yakni data yang diperoleh berfokus pada rumusan masalah pada rentang tahun 2019 s.d 2020.

3. Penyajian Data

Data yang diperoleh selanjutnya diklasifikasikan sesuai dengan variabel penelitian. Dalam penelitian ini, sebagian besar data yang disajikan akan berupa uraian deskriptif atau narasi, tabel, serta info grafis.

4. Kesimpulan dan Verifikasi

Kegiatan penyimpulan merupakan langkah lebih lanjut dari kegiatan reduksi dan penyajian data. Data yang sudah direduksi dan disajikan secara sistematis kemudian disimpulkan sementara. Selanjutnya, kesimpulan sementara itu perlu untuk diverifikasi guna mengecek keabsahan data.

Pemeriksaan keabsahan (trustworthiness) data dalam penelitian ini dilakukan dengan empat kriteria. Masingmasing adalah derajat: (1) kepercayaan (credibility), (2) keteralihan (transferability), (3) ketergantungan (dependability), dan (4) kepastian (conformability).

Adapun teknik yang digunakan untuk memverifikasi dan meningkatkan derajat kepercayaan data perolehan, dilakukan dengan teknik: (1) perpanjangan ke ikutsertaan, (2) ketekunan pengamatan, (3) triangulasi, (4) pemeriksaan sejawat, (5) kecukupan referensial, (6) kajian kasus negatif, dan (7) pengecekan anggota. Analisis menekankan pada penggalian isu-isu strategis terkait penempatan pangkalan aju militer sekaligus menelaah respon terhadap isu-isu tersebut. Konfirmasi hasil temuan berdasarkan analisis akan dihadapkan dengan data primer yang berasal dari survei, wawancara, maupun focus group discussion (FGD).

\section{PEMBAHASAN}

Kebijakan yang akan dikembangkan ke depan, diarahkan untuk tercapainya kemampuan, kekuatan dan gelar TNI yang mampu menjaga kedaulatan dan keutuhan wilayah NKRI serta keselamatan bangsa dalam tataran kekuatan pokok minimum (MEF) meliputi pembinaan dan penggunaan kekuatan TNI.

Kebijakan pembinaan TNI, yang meliputi kebijakan pembinaan kekuatan, pembinaan kemampuan dan gelar serta pembangunan kekuatan TNI, diarahkan untuk mencapai kekuatan dan kemampuan pada tataran kekuatan pokok minimum (MEF) dan dilakukan secara bertahap serta berkesinambungan melalui pemeliharaan, modernisasi dan pengadaan Alutsista baru dengan memberdayakan industri pertahanan dalam negeri; melaksanakan penataan organisasi didukung oleh SDM yang memiliki integritas moral, intelektual, kesamaptaan jasmani, dan kesejahteraan, melaksanakan pengembangan sistem dan metode Tri Matra terpadu serta menggelar kekuatan secara efektif dan efisien.

Pembinaan kekuatan pada dasarnya diarahkan untuk mencapai sasaran tertatanya struktur organisasi TNI sesuai Peraturan Presiden Republik Indonesia No. 10 Tahun 2010 tentang Susunan Organisasi TNI dengan mempertimbangkan right sizing dan terisinya struktur Satuan Operasional TNI di daerah perbatasan, daerah rawan konflik serta pulau-pulau terluar; meningkatnya kesiapan Alutsista dan material khusus TNI yang terpadu antar matra dengan memberdayakan industri pertahanan nasional; terpenuhinya kebutuhan personel yang memenuhi standar kompetensi dan kualifikasi serta terjamin kesejahteraannya; terpenuhinya kualitas dan kuantitas sarana prasarana dukungan; terpenuhinya peranti lunak peraturan perundangan tentang perbantuan, pengerahan dan penggunaan kekuatan TNI.

Langkah-langkah yang perlu diprioritaskan, antara lain :

1. Menata seluruh struktur organisasi TNI disesuaikan dengan Peraturan Presiden Republik Indonesia No.10 Tahun 2010 tentang Susunan Organisasi TNI;

2. Melaksanakan validasi Daftar Susunan Personel/Tabel Organisasi Personel dengan mempertimbangkan right sizing; pengisian Satuan Operasional TNI di daerah perbatasan, utamanya perbatasan darat di Kalimantan, Timor Leste dan Papua, daerah rawan konflik serta dua belas pulaupulau terluar;

3. Melaksanakan rematerializes Alutsista TNI melalui pemeliharaan secara terencana dengan memberdayakan fasilitas pemeliharaan angkatan yang dapat digunakan secara terpadu dan melaksanakan optimalisasi dukungan logistik TNI;

4. Melanjutkan pembentukan Satuan TNI Pasukan Reaksi Cepat Penanggulangan Bencana (PRCPB) maupun pembentukan Diklat Pusat Misi Pemeliharaan Perdamaian (PMPP);

5. Menyempurnakan doktrin Tri Matra Terpadu, Aturan Pelibatan, serta sistem dan manajemen 
pembinaan; melaksanakan pembinaan personel sesuai siklus pembinaan karier;

6. Optimalisasi pelayanan kesehatan matra untuk dapat digunakan secara terpadu;

7. Mengupayakan ketersediaan rumah non-dinas bagi prajurit, mendorong realisasi pemberian tunjangan khusus perbatasan dan tunjangan kinerja, serta mengupayakan pemenuhan tunjangan keahlian sesuai indeks yang ditentukan;

8. Melengkapi fasilitas latihan dan meningkatkan kualitas 10 komponen pendidikan;

9. Melaksanakan fungsi pengawasan melekat, penegakan hukum dan penyempurnaan peraturan serta peranti lunak yang berkaitan dengan pelaksanaan tugas;

10. Melanjutkan penataan administrasi kepemilikan aset-aset TNI yang bergerak maupun tidak bergerak.

Pembinaan kemampuan, diarahkan untuk mencapai terwujudnya intelijen TNI yang mampu melakukan pendeteksian dini atas segala kerawanan masalah pertahanan dan keamanan negara; terwujudnya kemampuan pertahanan TNI yang memiliki daya tempur tinggi dan profesional dalam menggunakan Alutsista TNI secara terpadu dalam tataran kekuatan pokok minimum (MEF); terwujudnya kemampuan keamanan TNI yang memiliki mobilitas tinggi di seluruh wilayah NKRI baik darat, laut maupun udara; meningkatnya kemampuan perbantuan kepada POLRI dan Pemerintah Daerah sesuai dengan peraturan yang berlaku; terlaksananya efektivitas kegiatan pemberdayaan wilayah pertahanan; meningkatnya kemampuan dukungan untuk penyelenggaraan tugas-tugas OMP dan OMSP (HARIPIN, 2017).

Dalam melaksanakan pembinaan kemampuan, langkah-langkah yang ditempuh antara lain: meningkatkan kemampuan deteksi dini dan koordinasi satuan kewilayahan; meningkatkan kualitas dan kuantitas Latihan Gabungan TNI; meningkatkan kemampuan prajurit TNI untuk melaksanakan tugas-tugas OMSP; melaksanakan kegiatan latihan pra-tugas bagi prajurit TNI yang akan melaksanakan penugasan baik OMP maupun OMSP; meningkatkan kemampuan manajemen logistik dan perbekalannya sesuai dengan kebutuhan untuk mendukung operasi; meningkatkan kemampuan Komando dan Pengendalian Satuan Operasional; meningkatkan kualitas Satuan PPRC dan PRCPB TNI melalui pendidikan dan latihan serta melengkapi peralatannya. Untuk penggelaran kekuatan, diarahkan guna terwujudnya efektivitas dan efisiensi pelaksanaan tugas pokok TNI dengan langkah-langkah memantapkan gelar kekuatan terpusat TNI, mengevaluasi gelar satuan kewilayahan untuk mendukung operasi-operasi di daerah perbatasan dengan negara tetangga dan pulau-pulau terluar dihadapkan pada perkembangan dinamika ancaman (Prasetyo and Sugeng, 2015).

\subsection{Pembangunan Kekuatan TNI Dalam \\ Pembangunan Pangkalan Aju}

Kebijakan pembangunan kekuatan TNI, diarahkan untuk meningkatkan dan menambah kemampuan dan kekuatan TNI menuju postur kekuatan pokok minimum (MEF) dengan konsep Tri Matra Terpadu secara bertahap dan berlanjut yang diatur dalam Renstra Pembangunan TNI. Sasaran pembangunan kekuatan TNI diarahkan untuk terwujudnya kesiapsiagaan TNI sebagai komponen utama pertahanan negara sesuai kekuatan pokok minimum (MEF); meningkatnya kondisi teknis peralatan Alutsista TNI sesuai dengan perkembangan teknologi; terwujudnya kekuatan TNI sesuai kekuatan pokok minimum (MEF); terlaksananya peningkatan sarana prasarana dan fasilitas pangkalan militer; terwujudnya gelar Satuan Operasional TNI yang efektif dan efisien; meningkatnya kemampuan dan perlengkapan Pasukan Khusus TNI (AD, AL, AU) yang mampu mendukung strategi peperangan asimetris (asymmetric warfare).

Untuk itu langkah-langkah yang menjadi prioritas adalah melaksanakan revitalisasi/modernisasi Alutsista TNI secara bertahap dan berlanjut guna peningkatan kemampuan daya tempur sesuai fungsi asasinya; melaksanakan relokasi dan peningkatan status gelar kekuatan TNI di wilayah perbatasan, daerah rawan konflik dan 12 pulau terluar; melaksanakan pengadaan Alutsista TNI secara bertahap sesuai kekuatan pokok minimum (MEF); melaksanakan pengadaan Alutsista Pasukan Khusus TNI (AD, AL, AU) dan melengkapi kebutuhan sesuai dengan standar peralatan Pasukan Khusus matra; pemberdayaan industri pertahanan nasional, dan peningkatan kerja sama dengan Perguruan Tinggi, Litbang, Kementerian Pertahanan/TNI; melaksanakan penghapusan Alutsista TNI yang tidak produktif sesuai perencanaan kekuatan pokok minimum (MEF) TNI; mendorong tersedianya alokasi anggaran untuk memenuhi kekuatan pokok minimum (MEF); terpenuhinya kekuatan personel TNI menuju kekuatan pokok minimum (MEF) dengan mempertimbangkan zero growth (Suhartono, 2010).

\subsection{Penggunaan Kekuatan dalam Pembangunan Pangkalan Aju}

Kebijakan penggunaan kekuatan TNI dengan mengedepankan keterpaduan tri matra dalam rangka melaksanakan operasi militer untuk perang (OMP) dan operasi militer selain perang (OMSP), dilaksanakan dalam rangka penyelenggaraan pertahanan negara dan/atau dalam rangka mendukung kepentingan nasional sesuai peraturan perundang-undangan.

Penggunaan kekuatan TNI pada OMP dilakukan setelah ada pernyataan perang yang dikeluarkan oleh Presiden melalui mekanisme pengambilan keputusan politik negara dengan pertimbangan bahwa tujuan penggunaan kekuatan TNI pada OMP merupakan jalan terakhir yang terpaksa harus dipilih setelah berbagai 
upaya damai dalam penyelesaian konflik antar negara tidak tercapai (RAMBE, 2016). OMP dilakukan dengan tujuan mempertahankan kedaulatan negara, keutuhan wilayah, serta keselamatan bangsa dan negara dari kekuatan militer negara lain yang melakukan agresi terhadap Indonesia. Penggunaan kekuatan TNI pada OMSP dilaksanakan berdasarkan kebijakan dan keputusan politik negara.

Sasaran penggunaan kekuatan diarahkan pada penangkalan dan pencegahan berbagai bentuk ancaman dari kekuatan militer asing yang akan melakukan agresi terhadap Indonesia; tersedianya data intelijen yang akurat, akuntabel dan tepat waktu; terlaksananya pengerahan kekuatan TNI di wilayah perbatasan, daerah rawan konflik dan dua belas pulau-pulau terluar dengan berpedoman pada Prosedur Tetap Operasi dan Aturan Pelibatan; terlaksananya penegakan hukum dan penjagaan keamanan di wilayah laut dan udara; tertanggulanginya pelanggaran wilayah dan pelanggaran hukum; terlaksananya pemberdayaan wilayah pertahanan untuk terciptanya Ruang, Alat Dan Kondisi (RAK) juang; terlaksananya pengerahan kekuatan TNI dalam melaksanakan OMSP.

Berdasarkan UU Nomor 3 Tahun 2002 tentang Pertahanan Negara, dimana dalam pasal 3 ayat (2) menyebutkan bahwa pertahanan negara disusun dengan memperhatikan kondisi geografi Indonesia sebagai negara kepulauan, strategi yang digunakan dalam menyelenggarakan OMP dirumuskan dalam bentuk Strategi Pertahanan Nusantara (SPN). Aktualisasi dari konsep pertahanan tersebut dikembangkan dengan strategi pertahanan nusantara yang membagi wilayah pertahanan menjadi tiga mandala untuk menghadapi musuh, yaitu mandala pertahanan luar, mandala pertahanan utama, dan mandala pertahanan dalam.

Untuk itu penggunaan kekuatan dalam OMP yang menjadi prioritas adalah melaksanakan operasi intelijen dan pemberdayaan satuan kewilayahan untuk memantau situasi wilayah; melengkapi material khusus pos-pos pengamat di wilayah perbatasan dan pulau-pulau terluar; menggelar kekuatan TNI untuk menjaga kedaulatan di perbatasan darat, laut dan udara; menyiagakan kekuatan terpusat untuk sewaktu-waktu dapat dikerahkan ke daerah konflik; melaksanakan pengamatan wilayah NKRI khususnya wilayah perbatasan darat, laut dan udara; menggelar satuan PPRC.

Penggunaan kekuatan dalam OMSP dilaksanakan sesuai kebijakan dan keputusan politik negara dengan prioritas menggelar kekuatan TNI untuk melaksanakan pengamanan perbatasan dengan negara tetangga dalam bentuk patroli terkoordinasi (Patkor); menggelar kekuatan TNI di daerah rawan konflik dan rawan pelanggaran hukum di laut dan udara; menggelar pengamanan Presiden dan Wakil Presiden beserta keluarganya; menyiagakan kekuatan TNI untuk melaksanakan operasi mengatasi gerakan separatis bersenjata, mengatasi pemberontakan bersenjata, mengatasi aksi terorisme, mengamankan objek vital nasional yang bersifat strategis, melaksanakan tugas perdamaian dunia, memberdayakan wilayah pertahanan, membantu tugas Pemerintah di daerah, membantu Kepolisian Negara RI, membantu mengamankan tamu negara, membantu menanggulangi akibat bencana, SAR, membantu Pemerintah dalam pengamanan pelayaran dan penerbangan; membangun kerja sama militer dengan negara lain, dengan berpedoman pada tiga substansi kerangka kerja sama militer yang ditetapkan oleh Kementerian Pertahanan, guna membangun saling kepercayaan, mencegah, konflik, dan bersama-sama mencari solusi terbaik, dalam bentuk patroli terkoordinasi, latihan bersama, pertukaran prajurit, kunjungan/ muhibah dan forum kerja sama militer lainnya; optimalsasi peran TNI dalam bentuk Bakti TNI dalam rangka mendukung Pembangunan Nasional dan peningkatan kesejahteraan masyarakat khususnya daerah terpencil dan tertinggal.

Di samping hal-hal tersebut di atas, ke depan dalam pembangunan kekuatan TNI akan dikembangkan manajemen dan strategi perencanaan TNI yang terpadu di antara ketiga Angkatan. Keterpaduan tersebut meliputi lima aspek, yaitu: perencanaan, operasi, pendidikan dan latihan, penyelenggaraan dukungan, dan pengadaan alutsista. Keterpaduan dalam aspek perencanaan, diwujudkan melalui sistem perencanaan top-down dan bottom-up yang di-olahyudha-kan pada tingkat Mabes TNI untuk menyinergikan kepentingan masing-masing Angkatan dan kepentingan TNI menjadi satu rumusan tri matra terpadu sehingga dapat merumuskan program secara terpadu sesuai dengan ketersediaan anggaran.

Keterpaduan dalam aspek operasi, diwujudkan melalui sinergitas antar Angkatan yang dimulai dari proses perencanaan, penyiapan dan gelar kekuatan, sehingga matra saling bekerja sama dan melengkapi sesuai kapasitas masing-masing, demikian pula keterpaduan di bidang Komando Pengendalian, komunikasi maupun organisasi bantuan tembakan, sehingga operasi akan lebih efektif dan efisien. Keterpaduan tersebut sampai dengan harmonisasi dan komposisi Alutsista yang akan operasi .

Keterpaduan dalam aspek pendidikan dan latihan, untuk mewujudkan sumber daya manusia TNI yang berkualitas dan memiliki pemahaman yang sama tentang kedudukannya sebagai prajurit TNI, maka perlu diwujudkan suatu pendidikan yang terintegrasi dalam aspek strata pendidikannya maupun kelembagaannya. Pada aspek latihan, memformulasikan keterpaduan tiaptiap matra guna mewujudkan kesiapsiagaan TNI dalam merespons ancaman, dilakukan melalui keterpaduan siklus latihan TNI yang telah ditetapkan dan mengacu pada pengembangan satu konsep Tri Matra Terpadu. Dalam rangka pemenuhan pelaksanaan tugas operasi dengan tugas-tugas khusus juga dilakukan latihan-latihan persiapan baik secara matra maupun gabungan dalam bentuk latihan pra-tugas, melaksanakan pemanfaatan infrastruktur latihan se-optimal mungkin dengan menggunakan sarana dan prasarana latihan yang dimiliki 
oleh masing-masing matra secara bersama-sama untuk dapat meningkatkan profesionalisme masing-masing matra.

Keterpaduan dalam aspek dukungan diwujudkan dalam bentuk optimalisasi fasilitas yang dimiliki matra dalam pembangunan infrastruktur serta instalasi militer berupa pangkalan aju (FOB), sehingga diperoleh efisiensi. Dalam rangka perawatan Alutsista dapat menggunakan fasilitas pemeliharaan dan perbaikan matra lain yang telah memadai, demikian pula dengan perawatan personel dapat dilaksanakan melalui fasilitas perawatan personel secara terpadu yang telah dimiliki oleh salah satu rumah sakit Satuan TNI di daerah. Fasilitas milik TNI lainnya dapat digunakan secara bersama oleh matra lain. Untuk mendapatkan efisiensi dalam pemenuhan kebutuhan Alutsista TNI guna mewujudkan kemampuan dan daya tangkal yang tinggi dalam merespons ancaman, TNI dalam merencanakan pengadaan Alutsista harus mencerminkan kepentingan Tri Matra Terpadu dan berorientasi pada keleluasaan, kepentingan serta kemampuan matra dengan mempertimbangkan faktor karakteristik geografi.

\subsection{Pangkalan Aju Udara dan Pangkalan Aju Laut}

Kawasan Pembangunan Pangkalan Angkatan Udara terletak di Kelurahan Karang Anyar Pantai Kecamatan Tarakan Barat. Pangkalan militer ini dibangun pada Kawasan bandara Juwata dengan lahan seluas 39 hektare dari total luas bandara yakni 238 hektare, sehingga pembangunan pangkalan militer ini tidak mengganggu aktivitas penerbangan domestik. Proses pembangunan Lanud Tarakan sudah dilaksanakan sejak tahun 2005, yang meliputi pematangan lahan, pembangunan markas Lanud, perkantoran, fasilitas pangkalan, pemukiman, sarana penerbangan, shelter, apron, taxyway serta fasilitas umum lainnya.

Letak Kalimantan Utara (Kaltara) yang berada di perbatasan merupakan tempat yang vital. Lanud Tarakan sejauh ini sudah sangat pesat, hal ini terlihat sudah adanya pembangunan shelter pesawat yang ditargetkan tahun 2019 akan selesai. Dengan adanya shelter pesawat ini, maka kedepan satu flight pesawat tempur mulai dari F16, Sukhoi, Hawk, T50, Super Tucano dan lain-lainnya akan di-standby-kan di Lanud Tarakan. Jumlahnya juga bervariasi mulai 8 hingga 10 pesawat, namun sifatnya hanya sementara.

Ke depan Lanud Tarakan akan diperluas, dengan adanya lahan seluas 15 hektare pemberian Pemkot. Tarakan. Komandan Lanud Tarakan akan melakukan koordinasi dengan Wali Kota Tarakan Sofian Raga, terkait rencana memperpanjang landasan menjadi 2.500 meter. Agar dapat mendaratkan segala jenis pesawat TNI AU dalam rangka operasi, khususnya pengamanan perbatasan (Sudiar, 2015). Posisi Provinsi Kalimantan Utara sebagai daerah perbatasan, membuat potensi pelanggaran wilayah kerap terjadi. Terutama dengan negara tetangga Malaysia. Untuk itu, sebagai salah satu penjaga keamanan perbatasan, Pangkalan Udara (Lanud)
Tipe B Tarakan akan memasang alat pemantau sejenis radar Automatic Identification System (AIS) untuk memantau keberadaan kapal asing. Komandan Pangkalan Udara (Lanud) Anang Busra Tarakan, Kolonel Pnb Didik Kristyanto mengatakan, sudah seharusnya wilayah Kaltara dipasang radar khusus untuk pemantauan.

Ke depanya Indonesia akan membangun radar namun fungsi radar itu akan fokus pada maritim. Kalau radar udara kita sudah punya, yaitu Satuan Radar 225 Tarakan. Apabila radar AIS sudah terpasang, maka pelanggaran kapal asing akan terpantau dan segera mengirim data. Jika ada kapal negara luar yang melakukan pelanggaran, data secara real time akan dikirim ke Lanud, selanjutnya data tersebut dikirim ke mabes. Diungkapkan, untuk pembangunan alat ini masih dalam penjajakan areal yang akan dipasang. Sebelum dibangun harus ada pengerasan lahan terlebih dahulu agar tidak mengganggu proses kerja radar.

Selain membangun alat pantau jenis radar pemantau Maritim, Lanud Tarakan juga terus berbenah dalam hal Sumber Daya Manusia (SDM) hingga penambahan infrastruktur. Bahkan menurut Didik, Panglima TNI AU melalui Kepala Staf Angkatan Udara memberikan perhatian terhadap Lanud yang ada di daerah perbatasan. Rencananya di 2030, akan ditempatkan pesawat tempur jenis Sukhoi di Lanud Tarakan (Mustari and Barnas, 2018). Selain AIS, TNI AU juga menempatkan pesawat tanpa awak (drone) di wilayah perbatasan untuk memperkuat pengawasan. Dua drone ditempatkan di Pulau Natuna perbatasan Indonesia dengan Laut China Selatan dan Kota Tarakan, Kalimantan Utara perbatasan RI-Malaysia.

Selain itu Panglima TNI Jenderal Gatot Nurmantyo pada Juni 2017 meresmikan Perluasan Pangkalan Utama Angkatan Laut XII Tarakan beserta Maritime Command Center (MCC) atau Pusat Komando Militer milik Indonesia di Tarakan, Kalimantan Utara. Lokasi MCC di Tarakan ini berdekatan dengan MCC milik Malaysia di Tawau dan MCC Filipina di Bongao. Pembukaan MCC dilakukan di Markas Komando Lantamal XIII Tarakan. Selain Gatot, hadir Menteri Pertahanan RI Ryamizard Ryacudu, Panglima Angkatan Tentera Malaysia Jenderal Tan Sri Dato' Sri Raja Mohamed Affandi bin Raja Mohamed Noor, dan Chief of Staff Armed Forces of the Philippines General Eduardo M Ano.

MCC diresmikan tidak hanya dalam rangka untuk mencapai keamanan di Laut Sulu. Namun, MCC adalah bentuk konkrit solidaritas 3 negara dalam menjaga keamanan di perairan ASEAN. Lenih dari itu, MCC merupakan salah satu bentuk usaha TNI mewujudkan program Presiden RI Joko Widodo, yang ingin Indonesia sebagai poros maritim dunia. "bentuk sinergitas di 3 MCC merupakan pembagian komunikasi informasi dan intelijen dalam mendukung hubungan bilateral. Dengan adanya kerja sama ini diharapkan mampu meredam dan meminimalisir (perompakan dan penculikan) di perairan yang menjadi perhatian bersama. TNI siap dalam 
menjaga keamanan negara dan wilayah sekitarnya, sebagai garda terdepan kerja sama dengan 2 negara lain (Sopia, 2017). Beberapa hal penting yang harus dilakukan ketiga MCC di 3 negara dalam rangka meningkatkan kerja sama. Pertama, ketiga MCC harus meningkatkan aspek komunikasi, surveillance, dan komputerisasi, dalam upaya menghasilkan analisis yang akurat dan cepat dalam membuat keputusan komando dan pengendalian. Kedua, TNI diwajibkan untuk meningkatkan profesionalisme agar hasil yang dikeluarkan dapat maksimal pada setiap operasi. Ketiga, seluruh MCC perlu mengembangkan mekanisme koordinasi dalam sharing informasi dengan satuan terkait agar mendapatkan jenis data terkini dalam mendukung operasi (Haripin, 2017).

\subsection{Sinergi Masyarakat Sipil dan TNI dalam Pembangunan Pangkalan Aju}

Salah satu faktor tercapainya tujuan terbebasnya suatu wilayah yang dari ancaman adalah sinergi yang baik antara masyarakat sipil, pemerintah daerah dan komponen militer. Sinergitas penanganan ancaman nirmiliter dan pembangunan tata ruang pertahanan daerah setidaknya melibatkan dua belas sektor yang terdiri dari pemerintah, militer, kepolisian, dan masyarakat sipil. Masing-masing sektor memiliki perwakilan dan/atau pelaksana tugas pokok di daerahnya, termasuk di daerah. Masing-masing penanggung jawab ini memiliki wewenang dan kewajiban tugas. Sinergitas peran ini sangat diperlukan untuk mendorong penanganan ancaman nirmliter dan pembangunan tata ruang pertahanan daerah menjadi lebih efektif dan efisien. Sinergitas peranan ini diharapkan dapat mencapai tujuan-tujuan strategis baik secara makro, mikro dan jangka panjang ataupun menengah, dan pendek.

Dari hasil wawancara yang dilaksanakan, maka peneliti bisa menjelaskan bahwa bentuk-bentuk kegiatan kerja sama sudah dilaksanakan. Adapun kerja sama sipilmiliter dalam pengelolaan daerah tempat dibangunnya pangkalan Aju adalah upaya komunikasi yang baik antar pemerintah daerah, masyarakat sipil, dan TNI yang dilakukan melalui FGD rutin, pembinaan desa-desa sekitar, pengembangan wilayah ekonomi di sekitar pangkalan Aju, serta agenda-agenda pembinaan dan sosialisasi mengenai potensi ancaman yang kemungkinan akan terjadi di wilayah tersebut. Hal ini ternyata efektif untuk menekan konflik sosial budaya antara masyarakat sipil dan TNI pendatang yang sedang melakukan proses pembangunan Pangkalan Aju. Pada akhirnya dengan terciptanya kerja sama antar instansi sipil dan militer akan menjawab harapan dan penekanan dari pemerintah untuk memadukan semua fungsi negara supaya dapat berjalan secara selaras dan berdayaguna dalam menunjang program pembangunan dan peningkatan kesejahteraan masyarakat, bangsa dan negara.

\section{KESIMPULAN}

Dihadapkan dengan beratnya medan di sekitar wilayah perbatasan, ditambah lagi dengan adanya potensi konflik di Laut Natuna Utara dan Selat Makassar, maka sangat bijak jikalau sistem pertahanan NKRI terkait perbatasan di sesuaikan kembali. Tetapi sebaiknya dibuat tidak secara instan serta tidak terkait dengan "gelar pasukan TNI" yang sudah ada (existing), serta dalam rencana akhirnya dibuatlah pemantapan dan pelaksanaan pembangunan Pangkalan Aju. Ada dua contoh Kemhan melakukan pembangunan sarana pertahanannya di perbatasan akan tetapi kemudian seolah "muspro" (tidak bermanfaat).

Hal itu bisa dilihat di daerah Seluas di Kalimantan Barat dan pulau Nipah di Batam. Di wilayah Seluas, Kemhan membangun Gedung pertahanan di tahun 90'an, sampai sekarang sama sekali tidak difungsikan. Begitu juga di Pulau Nipah di Batam, perbatasan dengan Singapura. Pulau yang tadinya nyaris tenggelam itu di reklamasi dan dibangun untuk menempatkan Kompi Marinir di sana. Setelah sarana-prasarana tersebut berdiri serta sempat dijadikan sebagai pangkalan, hingga kemudian ditinggalkan dan kini "muspro". Dana yang Miliaran rupiah sama sekali tidak bermanfaat sebagaimana mestinya.

Idealnya Armada, Koops dan Kodam diperkuat sesuai dengan perspektif realitas ancaman yang ada. Di Kodam, Korem, Kodim, Koramil yang dekat dengan perbatasan misalnya, kita melihat mereka belum ditunjang oleh Mobilitas Udara (Mobud) dan Lintas Logistik Laut yang sewajarnya. Mereka (TNI tiga Matra) hingga kini berusaha agar dapat melakukan patroli udara yang berkesinambungan di sepanjang perbatasan dan juga terbatas kemampuannya dalam memproyeksikan kekuatannya ke berbagai trouble spots di wilayah perbatasan meski itu setingkat Regu/unit tempur. Demikian juga untuk perimbangan kekuatan relatif dengan negara tetangga, semestinya perlu juga di "gelar" kekuatan pertahanan, khususnya untuk daerah sekitar kota-kota perbatasan yang saling berdekatan dengan Kota-kota negara tetangga (P.Batam, Kalimantan, Papua \& NTT). Khususnya di wilayah-wilayah strategis perbatasan seperti Pulau Natuna, Wilayah Tanjung Datu atau Pulau Tarakan seperti yang digagas oleh Bappenas dan Kemhan.

Untuk kepentingan pertahanan wilayah baik laut, udara serta territorial darat, sekaligus dalam rangka menjaga perimbangan kekuatan pertahanan dengan negara tetangga serta untuk menggerakkan perekonomian wilayah perbatasan perlu adanya penambahan dan pergeseran kekuatan di lokasi-lokasi tersebut; khususnya gelar Artillery pertahanan darat dan Pantai; penambahan daya dukung bandara di perbatasan seperti di Tarakan, Nunukan-Malinau-Sanggoledo dan Putu Sibau hingga punya Landasan Pacu sepanjang 2650 meter agar dapat memfasilitasi kepentingan pesawat tempur dan pesawat angkut. Pembangunan satu Brigade Inf di Kalimantan Utara dan Marinir di Natuna atau 
Tanjung Pinang dengan penguatan Lanal serta Lanudnya. Kekuatan TNI AL juga perlu diperkuat di Pangkalan Utama Kalimantan Utara hingga Patroli Lintas Laut Militer untuk mengimbangi pihak tetangga yang menjadikan Sabah sebagai Armada Timur negaranya.

\section{SARAN}

Pada akhirnya situasi yang kita perhatikan adalah perlunya gelar kekuatan yang berfungsi dengan baik di perbatasan sesuai dengan persepsi ancaman nyata. Pemerintah akhirnya mempercepat implementasi pembangunan kekuatan secara realistis, sehingga gelar pasukan yang dibuat menjadi efektif, dengan harapan wilayah perbatasan dan wilayah strategis di sekitarnya dapat terjaga serta termonitor dengan baik, sehingga penyusupan entitas asing dapat dilakukan pencegahan. Dapat dibayangkan, secara aktual banyak pos-pos TNI di perbatasan, yang secara teoretis sesungguhnya tidak bisa berbuat banyak, karena mereka tidak diperlengkapi dengan sarana yang semestinya. Mereka hanya sekadar ada untuk sesuatu yang nyaris tidak bermakna apa-apa. Maka dari itu pembangunan pangkalan aju militer merupakan langkah cerdas dari pemerintah untuk merealisasikan proyeksi deterrence power -nya. Upayaupaya ini juga harus didukung dengan mekanisme kerja sama yang baik antara setiap elemen di wilayah pengembangan pangkalan aju, utamanya adalah dukungan dari masyarakat sipil setempat.

\section{DAFTAR PUSTAKA}

Amaritasari, I. (2015) 'Keamanan Nasional dalam Konsep dan Standar Internasional', Jurnal Keamanan Nasional.

HARIPIN, M. (2017) 'Military Operations Other Than Warfare and Problems of Military Professionalism in Democratizing Indonesia September', Graduate School of International Relations Ritsumeikan University, (September 2017), pp. 1-58.

Hutri, D., Sitorus, H. and Santosa, A. I. (2020) 'Analisis Dukungan Logistik Wilayah Operasi Udara Di Pangkalan Tni Angkatan Udara Roesmin Nurjadin Pekanbaru', Strategi Pertahanan Udara.

Kant, I. (2015) 'Perpetual peace', in Conflict After the Cold War: Arguments on Causes of War and Peace. doi: 10.7312/kant92280-002.

Lubis, R. R. (2018) 'Sekuritisasi Isu Keamanan Maritim Dalam Mendukung Diplomasi Pertahanan Indonesia di Admm Plus On Maritime Security', Jurnal Pertahanan \& Bela Negara, 8(1), pp. 27-44. doi: 10.33172/jpbh.v8i1.264.

Miles, M. B. and Huberman, M. A. (2012) Analisis Data Kualitatif: Buku Sumber Tentang Metode-Metode Baru, Universitas Indonesia_UI Press.

Mustari, B. and Barnas, R. (2018) 'Archipelago Sea Defense Strategy in Realizing Indonesia as a World of Maritime Axis', Jurnal Prodi Strategi Perang
Semesta.

Prasetyo, T. B. and Sugeng, B. (2015) 'Improving The Quality Of Human Resources In The Field Of Defense Industry Towards Aformidable State Defense Triyoga Budi Prasetyo dan Sugeng Berantas', Jurnal Pertahanan April 2015, Volume 5, Nomor 1 175, 5(1), p. 175.

Rambe, M. B. (2016) Tinjauan Yuridis Terhadap Penggunaan Pesawat Tanpa Awak (Uav) Dalam Menjaga Perbatasan Negara, jurnal.untan.ac.id.

Sopia, S. (2017) 'TNI Dirikan Pusat Komando Militer di Tarakan', pp. 1-4.

Sudiar, S. (2015) 'Pembangunan Wilayah Perbatasan Negara: Gambaran Tentang Strategi Pengelolaan Kawasan Perbatasan Darat di Provinsi Kalimantan Utara', Jurnal Administrative Reform, 3(4), pp. 489500 .

sugiono (2011) metode penelitian pendidikan (pendekatan kuwantitatif,kuwalitatif,R\&D), Alfabbeta Pres.

Suhartono, A. (2010) 'Membangun Budaya Maritim Dan Kearifan Lokal Di Indonesia: Perspektif Tni Angkatan Laut', Prosiding Icssis.

Al Syahrin, M. N. (2018) 'Kebijakan Poros Maritim Jokowi dan Sinergitas Strategi Ekonomi dan Keamanan Laut Indonesia', Indonesian Perspective, 3(1), p. 1. doi: 10.14710/ip.v3i1.20175.

Tarakan, W. (2012) Rencana Tata Ruang Wilayah Kota Tarakan Tahun 2012 - 2032. Indonesia. Available at: https://peraturan.bpk.go.id/Home/Download/63056/K OTA_TARAKAN_4_2012.pdf ttg Rencana Tata Ruang Wilayah Kota Tarakan Tahun 20122032.pdf_2.pdf.

Thontowi, J. (2015) 'Hukum Dan Diplomasi Lokal Sebagai Wujud Pemecahan Masalah Di Wilayah Perbatasan Kalimantan Dan Malaysia', Yuridika, 30(3), p. 353. doi: 10.20473/ydk.v30i3.1951.

Usmita, F. (2012) 'Universitas Indonesia Disengagement; Strategi Penanggulangan Terorisme Di Indonesia', Skripsi, Fakultas Ilmu Sosial Dan Ilmu Politik Program Studi Kriminologi Depok.

Wangke, H. (2017) 'Kerja Sama Indonesia-Malaysia dalam Pengelolaan Perbatasan di Kalimantan', p. 166. Available at: https://berkas.dpr.go.id/puslit/files/buku_tim/bukutim-public-75.pdf. 